\title{
Ticagrelor Use and Practice Pattern among Canadian Cardiac Surgeons
}

\author{
Ahmed Makhdoum ${ }^{1}$, Subodh Verma ${ }^{1}$, Bobby Yanagawa ${ }^{1}$, Nitish Dhingra ${ }^{1}$, Rachel \\ Eikelboom ${ }^{2}$, Thin Vo ${ }^{3}$, Joel Bierer ${ }^{4}$, Jessica Luc ${ }^{5}$, Olina Dagher ${ }^{2}$, Andreanne Cartier ${ }^{6}$, \\ olivier vaillancourt ${ }^{7}$, Kier Forgie ${ }^{8}$, Gianluigi Bisleri ${ }^{1}$, and Terrence Yau $^{9}$ \\ ${ }^{1}$ University of Toronto \\ ${ }^{2}$ Affiliation not available \\ ${ }^{3}$ University of Ottawa \\ ${ }^{4}$ Dalhousie University \\ ${ }^{5}$ The University of British Columbia \\ ${ }^{6}$ Laval University \\ ${ }^{7}$ McGill University \\ ${ }^{8}$ University of Alberta \\ ${ }^{9}$ Toronto General Hospital
}

April 3, 2021

\begin{abstract}
Background and Aim: The P2Y12 platelet receptor inhibitor ticagrelor is widely used in patients following acute coronary syndromes or in those who have received coronary stents. Bentracimab is a monoclonal antibody-based reversal agent that is being formally evaluated in a Phase 3 clinical trial. Here, we probe the knowledge, attitudes, and practice patterns of cardiac surgeons regarding their perioperative management of ticagrelor and potential application of a ticagrelor reversal agent. Methods: A questionnaire was developed by a working group of cardiac surgeons to inquire into participants' practices and beliefs regarding ticagrelor and disseminated to practicing Canadian cardiac surgeons. Results: A total of 70 Canadian cardiac surgeons participated. Bleeding risk was identified as the most significant consideration when surgically revascularizing ticagrelor-treated patients (90\%). There is variability in the duration of withholding ticagrelor prior to coronary artery bypass graft procedure in a stable patient; $44.3 \%$ wait 3 days and $32.9 \%$ wait 4 days or longer. Currently, $14.3 \%$ of cardiac surgeons prophylactically give platelet transfusions and/or fresh frozen plasma intraoperatively following protamine infusion in patients who have recently received ticagrelor. Interestingly, $47.1 \%$ of surveyed surgeons were aware of a reversal agent for ticagrelor, $91.4 \%$ of cardiac surgeons would consider utilizing a ticagrelor reversal agent if available, and $51.4 \%$ acknowledged that the introduction of such an agent would be a major advance in clinical practice. Conclusions: The present survey identified ticagrelor-related bleeding as a major concern for cardiac surgeons. Surgeons recognized the significant unmet need that a ticagrelor reversal agent would address.
\end{abstract}

\section{Hosted file}

Ticagrelor Draft FINAL Apri13.pdf available at https://authorea.com/users/384085/articles/ 516548-ticagrelor-use-and-practice-pattern-among-canadian-cardiac-surgeons

\section{Hosted file}

Ticagrelor Figure 1.pptx available at https://authorea.com/users/384085/articles/516548ticagrelor-use-and-practice-pattern-among-canadian-cardiac-surgeons 


\section{Hosted file}

Ticagrelor Figure 2.pptx available at https://authorea.com/users/384085/articles/516548ticagrelor-use-and-practice-pattern-among-canadian-cardiac-surgeons

\section{Hosted file}

Ticagrelor Figure 3.pptx available at https://authorea.com/users/384085/articles/516548ticagrelor-use-and-practice-pattern-among-canadian-cardiac-surgeons

\section{Hosted file}

Ticagrelor Figure 4.pptx available at https://authorea.com/users/384085/articles/516548ticagrelor-use-and-practice-pattern-among-canadian-cardiac-surgeons 